\title{
Abnormal lymphocyte function is secondary to drug-induced autoimmunity
}

\author{
S. PUGH, B. PELTON, E. B. RAFTERY, AND A. M. DENMAN \\ From the Clinical Research Centre, Watford Road, Harrow, Middlesex HA1 $3 U \mathrm{UJ}$
}

\begin{abstract}
Pugh, S., Pelton, B., Raftery, E. B., and Denman, A. M. (1976). Annals of the Rheumatic Diseases, 35, 344-348. Abnormal lymphocyte function is secondary to drug-induced autoimmunity. Abnormal lymphocyte function has been frequently reported in patients with connective tissue diseases but its significance has been uncertain. Sequential studies of lymphocyte function were carried out in patients receiving the $\beta$-adrenergic blocking drug practolol (Eraldin) both before and during the development of autoimmune complications. No evidence was obtained that abnormal lymphocyte function presaged the onset of autoimmunity, and when these tests did show deficient responses these could be correlated with disease activity in general.
\end{abstract}

Abnormal tests of lymphocyte function, such as reduced numbers of T-cells and impaired responses to mitogens, have been reported in autoimmune and chronic inflammatory diseases (Lockshin and others, 1975). Although there are theoretical reasons for attributing autoimmune disease to depressed $T$ lymphocyte function, it is not clear whether the reported abnormalities are of primary pathogenetic importance or merely secondary to disease activity.

In 1973 we described 3 cases of a systemic lupus erythematosus (SLE) syndrome induced by practolol (Raftery and Denman, 1973). Since then other important complications have been described such as the oculocutaneous syndrome (Felix, Ive, and Dahl, 1974; Wright, 1975) and sclerosing peritonitis (Brown and others, 1974). Moreover, the majority of patients with these side effects have serum autoantibodies (Amos, Brigden, and McKerron, 1975).

In a preliminary attempt to elucidate the pathogenesis of these complications we noted that lymphocytes from patients with the SLE syndrome had abnormal responses to mitogens in vitro, whereas no immune response to the drug itself could be detected. This suggested that sequential observations of lymphocyte function in patients receiving practolol would make it possible to determine whether abnormal lymphocyte function precedes the development of autoimmunity.

This paper shows that depressed lymphocyte transformation in patients receiving practolol could be correlated with the activity of the disease which necessitated treatment with this drug, or was induced by it. No evidence was obtained that $\vec{\varphi}$ abnormal lymphocyte function predisposed th patient to the development of autoimmunity.

\section{Patients and methods}

The patients who were studied fall into three categories. Group 1 consisted of 10 patients with definite practolol toxicity in the form of skin lesions in 6 and the oculocutaneous syndrome in the remainder. All had antinuclear antibody (ANA). These patients had already developed complications by the time they were investigated.

Group 2 The second group consisted of 122 consecutive patients with ischaemic heart disease seen at this centre as inpatients or outpatients. The incidence of ANA (titre $>1: 10$ ) in this group was $23 \%$. These patients were studied on at least two occasions over a period of 18 months. 77 patients were receiving practolol, and 45 were not receiving a beta blocking drug (see Table $\mathrm{I}$.

Group 3 contained 20 consecutive patients (mean age $\bigcirc$ 60 years, range 48-72) of whom 18 had recently developed angina pectoris and 2 cardiac arrythmias. Patients who $\frac{}{0}$ were already receiving treatment when first seen, who had an ESR $>10 \mathrm{~mm} / \mathrm{h}$, or who had any associated disease, o were excluded. The patients were given practolol $(300$ $800 \mathrm{mg} / \mathrm{d}$ ) but, apart from glyceryl trinitrate, received 0 no other drugs. Blood samples were taken before starting $\omega$ practolol, and $1,2,3,6$, and 9 months after starting the $\sigma$ drug.

\section{LABORATORY TESTS Autoantibodies}

Sera were examined for autoantibodies by indirect immunofluorescence using multiple block sections of $\overrightarrow{\mathbb{D}}$ 
Table I Patients in group 2

\begin{tabular}{|c|c|c|c|c|c|}
\hline Patients & No. & $\begin{array}{l}\text { Age } \\
\text { (years) }\end{array}$ & $\begin{array}{l}\text { Dosage } \\
(m g / d)\end{array}$ & Other drugs & Associated diseases \\
\hline On practolol & 77 & $\begin{array}{l}63 \\
(41-80)\end{array}$ & $300-800$ & $\begin{array}{l}\text { Glyceryl trinitrate } \\
\text { Digoxin } \\
\text { Frusemide }\end{array}$ & $\begin{array}{l}\text { Acute infections } \\
\text { Recent myocardial } \\
\text { infarction }\end{array}$ \\
\hline Not on practolol & 45 & $\begin{array}{l}60 \\
(39-81)\end{array}$ & - & $\begin{array}{l}\text { Methyl dopa } \\
\text { Guanethidine } \\
\text { Reserpine } \\
\text { Phenformin } \\
\text { Antibiotics } \\
\text { Aspirin }\end{array}$ & $\begin{array}{l}\text { Rheumatoid arthritis } \\
\text { Hypertension } \\
\text { Diabetes }\end{array}$ \\
\hline
\end{tabular}

rat liver, stomach, kidney, and human thyroid, and rabbit antihuman immunoglobulin (Burroughs Wellcome) at $1: 10$ dilution.

\section{Lymphocyte transformation}

Blood mononuclear cells separated by Ficoll-Triosil sedimentation were cultured by a standard micromethod using Eagle's Dulbecco medium and pooled normal human serum. Dose response curves to mitogen stimulation were obtained using purified phytohaemagglutinin (PHA; Burroughs Wellcome), concanavalin A (Con A; Calbiochem), and pokeweed mitogen (PWM; Gibco) (Lance and Knight, 1974). Culture conditions were standardized throughout but the isotope used in different studies was either ${ }^{14} \mathrm{C}$ thymidine $0.08 \mu \mathrm{Ci}$, specific activity $62 \mathrm{mCi} / \mathrm{mmol}$, or ${ }^{3} \mathrm{H}$ thymidine $0.167 \mu \mathrm{Ci}$, specific activity $150 \mathrm{mCi} / \mathrm{mmol}$ (Radiochemical Centre, Amersham) as will be indicated in the results.

\section{Lymphocyte subpopulations}

Rosette formation with sheep red cells was used as a marker for T lymphocytes (Wybran, Carr, and Fudenberg, 1972). Surface immunoglobulin detected by indirect immunofluorescence was used as a marker for B lymphocytes (Brown and Greaves, 1974). The specificity of the anti-immunoglobulin serum (Burroughs Wellcome) was verified by immunoelectrophoresis before use.

Practolol blood levels were measured by a colorimetric method.

\section{Statistics}

All analyses were performed on log transformed data.

\section{Results}

Of the first group of patients with established practolol toxicity who were studied the in vitro lymphocyte responses of the 6 patients with skin rashes were normal but those from 2 of the 4 patients with the oculocutaneous syndrome were clearly depressed (Fig. 1). This observation confirmed that some patients with practolol toxicity and associated autoimmunity develop such abnormalities.

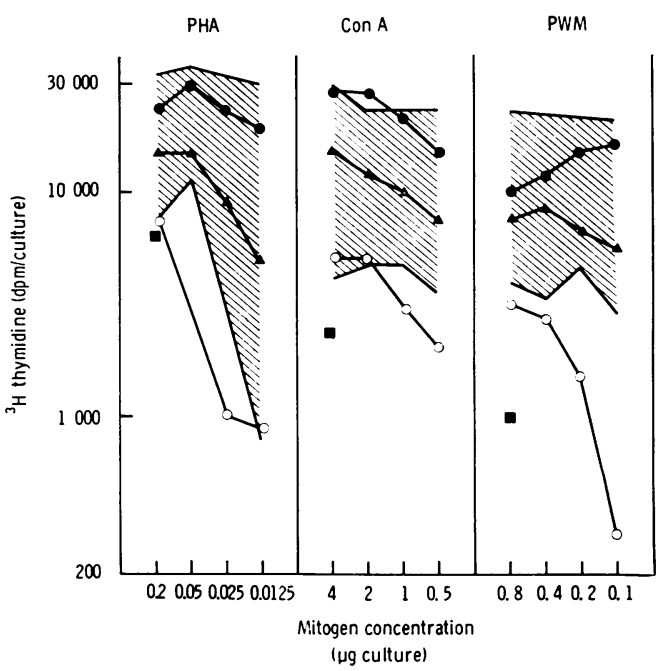

FIG. 1 Dose response curves from 4 patients with the oculocutaneous syndrome. Hatched area represents normal range. Unstimulated cultures 120 (50-280) dpm mean \pm 2 SD. PHA = phytohaemagglutinin; Con $A=$ concanavalin $A ; P W M=$ pokeweed mitogen

Table II Patients from second series divided into groups according to ESR, ANF, and whether or not they were taking practolol. The number of patients with abnormal responses (defined in text) in each group is shown together with the total number in that group

\begin{tabular}{|c|c|c|c|c|}
\hline \multirow{3}{*}{$\frac{\text { Patients }}{\text { Off practolol }}$} & $A N F$ & Negative & \multirow{2}{*}{$\frac{A N F}{E S R<20 \mathrm{~mm} / \mathrm{h}}$} & \multirow{2}{*}{$\frac{\text { Positive }}{E S R>20 \mathrm{~mm} / \mathrm{h}}$} \\
\hline & $E S R<20 \mathrm{~mm} / \mathrm{h}$ & $E S R>20 \mathrm{~mm} / \mathrm{h}$ & & \\
\hline & $3 / 18 \quad(16 \%)$ & $7 / 13 \quad(53 \%)$ & $0 / 3$ & $0 / 2$ \\
\hline On practolol & $6 / 36 \quad(16 \%)$ & $11 / 17 \quad(64 \%)$ & $3 / 13 \quad(23 \%)$ & $5 / 11 \quad(45 \%)$ \\
\hline
\end{tabular}


Accordingly, these studies were repeated in a large number of patients taking practolol in order to determine the correlation between lymphocyte function and the appearance of ANA used as a marker for the development of autoimmunity (group 2). Depressed lymphocyte responses, defined as subnormal response to one or more mitogens in at least the two lowest concentrations, were observed in a high proportion of these patients (Table II). The results were analysed with respect to disease activity, practolol treatment, and the development of ANA. Depressed responses to mitogens could only be correlated with a raised erythrocyte sedimentation rate (ESR) (Fig. 2), a test which reflects disease activity in general, but not with the presence

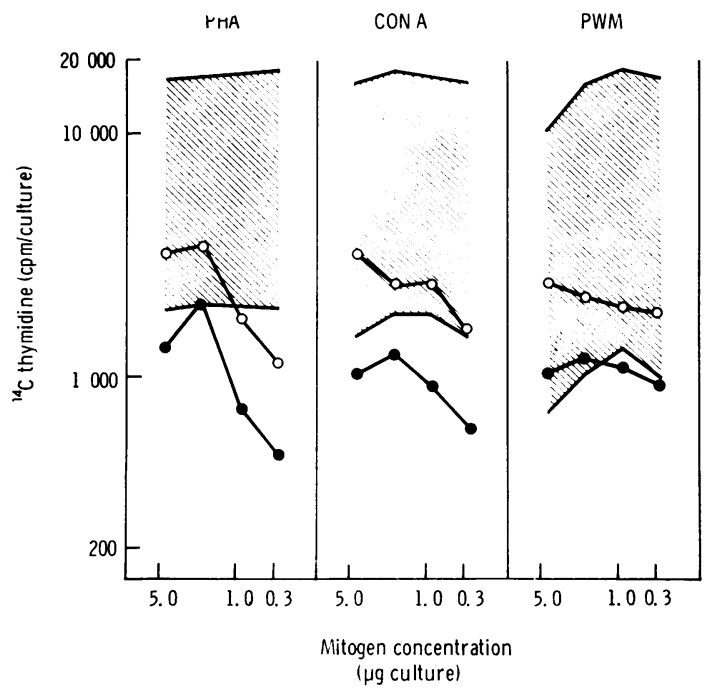

FIG. 2 Mean dose response curves from patients in group 2. $0=E S R<20, n=63 ; \bullet=E S R>20, n=43$. Hatched area represents range from a group of normals. $P<0.005$ for all points except $P H A$ and Con $A$ at $2 u g$ where $P<0.05$ ('t' test). Unstimulated cultures $170(20-1300) \mathrm{cpm}$ mean $\pm 2 S D$ of ANA. In addition, no correlation was found between lymphocyte function and practolol treatment with respect to dose, blood level, or duration of treatment. These findings suggested that the depression of lymphocyte function seen in patients with practolol toxicity is more likely to reflect nonspecific disease activity than an event of primary pathogenetic importance.

In order to confirm this impression another group of carefully defined patients (group 3) was studied at regular intervals before and during treatment with practolol over a 9-month period. 4 of the patients were withdrawn before the end of the study with complications (Table III). With one exception none of the patients in this group showed any depression of lymphocyte transformation nor was there any

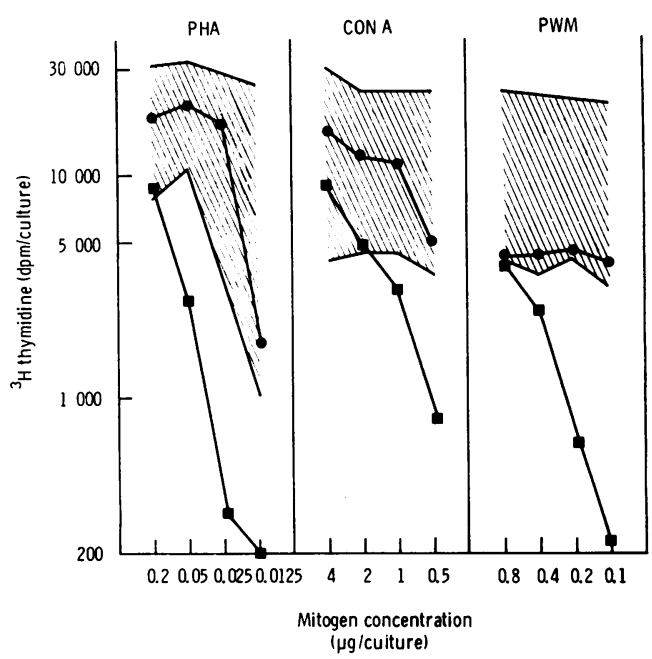

F I G. 3 Sequential dose response curves from patient K.G. who developed polymyositis. $\bullet=$ after 3 months on practolol; $\mathbf{\square}=$ after 6 months on practolol. Hatched area represents the normal range. Unstimulated cultures $\bullet=84$ dpm, $\square=94 \mathrm{dpm}$. (Normal range 50-280 dpm)

Table III Patients from group 3 withdrawn before the end of study

\begin{tabular}{|c|c|c|c|}
\hline Patient & $\begin{array}{l}\text { Dose } \\
(m g / d)\end{array}$ & $\begin{array}{l}\text { Time on practolol } \\
(m)\end{array}$ & Reason for withdrawal \\
\hline H.S. & 300 & 3 & $\begin{array}{l}\text { ANA rose from } 1: 10-1: 80 \text {. Complained of } \\
\text { dry eyes. No signs, intercellular anti- } \\
\text { body negative }\end{array}$ \\
\hline L.C. & 300 & 3 & $\begin{array}{l}\text { ANF rose from } 0 \text { to } 1: 160 \text {. Complained of } \\
\text { muscular pain }\end{array}$ \\
\hline K.S. & 600 & 6 & $\begin{array}{l}\text { Developed typical hyper-keratotoic skin } \\
\text { lesions }\end{array}$ \\
\hline K.G. & 600 & 6 & Developed polymyositis \\
\hline
\end{tabular}


significant change in numbers of circulating $T$ and B lymphocytes. However, one patient developed vague muscular aches and pains and an ANA titre of $1: 10$ three months after starting practolol treatment. At this time her lymphocyte response to mitogens were normal. Since her angina was poorly controlled, the dose of practolol was increased from 300 to $600 \mathrm{mg}$ daily. Three months later she developed a severe polymyositis with proximal muscle weakness. Her creatinine phosphokinase level was 1400 and the ANA titre had increased to $1: 180$. Her lymphocyte responses were now obviously and reproducibly abnormal. The relationship between treatment with practolol and this patient's disease is uncertain. However, its onset clearly preceded the development of abnormal lymphocyte responses (Fig. 3).

\section{Discussion}

Abnormal lymphocyte function has been described in several autoimmune and chronic inflammatory diseases (Lockshin and others, 1975) although there is little agreement about the reproducibility or significance of these findings. Some of the variation in results can be attributed to technical factors but in any event there has been no easy way of determining whether such abnormalities are of primary pathogenetic importance or the result of nonspecific disease activity. Autoimmunity has been attributed to the breakdown of a normal suppressor function mediated by $\mathrm{T}$ lymphocytes (Allison, Denman, and Barnes, 1971). This could follow a number of events including the destruction of $\mathrm{T}$ lymphocytes by virus infection or their progressive loss with age in genetically susceptible individuals. Drugs which block $\beta$-adrenergic receptors could conceivably inactivate lymphocyte populations directly. The ability of drugs which react with adrenergic receptors on lymphoid cells to modulate their activity in vitro has been frequently shown (Hadden, Hadden, and Middleton, 1970; Sherman, Smith, and Middleton, 1973). It seemed plausible, therefore, that $\beta$-adrenergic blocking drugs might selectively interfere with lymphocyte subpopulations in vivo, thereby abrogating control mechanisms which normally prevent the emergence of autoimmune disease.
Thus, serial tests of lymphocyte function in patients receiving practolol, a proportion of whom would be expected to develop side effects, gave some hope of determining whether the ablation of $T$ lymphocyte function predisposes to autoimmune disease. In the event no evidence was obtained that selective immunosuppression precedes the development of autoimmune disease. Abnormal responses to mitogens were found in a high proportion of the patients studied but these could be correlated with disease activity in general. In contrast no correlation was found between abnormal lymphocyte function and the development of antinuclear antibody. Furthermore, autoimmune disease when it did ensue was not foreshadowed by abnormalities of lymphocyte function. Thus, this study failed to produce any evidence that drug-induced autoimmunity, at least, results from the prior eradication of T lymphocyte function. Nevertheless, lymphocyte transformation and population markers are of limited value as tests of immunosuppressive potency even in patients receiving cytotoxic drugs (Swanson and Schwarz, 1967). In vitro systems of greater physiological relevance (Platts-Mills and Ishizaka, 1975) may show that drugs such as practolol do indeed have selective immunosuppressive effects.

It is also apparent from this study that current tests of lymphocyte function cannot be used to predict the onset of autoimmune disease and other complications in patients receiving practolol and by inference, other drugs with similar side effects. Moreover, a variety of tests has failed to show that patients receiving practolol develop antibodies to the drug itself. The protean nature of these complications is of great interest with respect to spontaneous autoimmune disease since our studies show that the relationship between practolol and its side effects could not have been deduced from any obvious pharmacological or immunogenic effects of the drug. On present evidence other mechanisms must be invoked.

The authors are indebted to Dr. Stella Knight for help in standardizing lymphocyte function tests and to Dr. H. K. Adam for assaying blood levels of practolol at the ICI Laboratories, Alderley Park, Macclesfield, Cheshire.

\section{References}

Allison, A. C., Denman, A. M., AND Barnes, R. D. (1971) Lancet, 2, 135 (Co-operating and controlling functions of thymus-derived lymphocytes in relation to autoimmunity)

Amos, H. E., Brigden, W. D., AND MCKerRoN, R. A. (1975) Brit. med. J., 1, 598 (Untoward effects associated with practolol: demonstration of antibody binding to epithelial tissue)

Brown, G., AND Greaves, M. F. (1974) Europ. J. Immunol., 4, 302 (Cell surface markers for human T and B lymphocytes)

Brown, P., BadDeley, H., Read, A. E., Davies, J. D., AND McGarry, J. (1974) Lancet, 2, 1477 (Sclerosing peritonitis, an unusual reaction to a $\beta$ adrenergic blocking drug (practolol) 
Felix, R. H., Ive, F. A., AND DAHL, M. G. C. (1974) Brit. med. J., 4, 321 (Cutaneous and ocular reactions to practolol)

Hadden, J. W., Hadden, E. M., AND Mmdleton, E. (1970) Cell. Immunol., 1, 583 (Lymphocyte blast transformation. 1. Demonstration of adrenerigic receptors in human peripheral lymphocytes)

LANCE, E. M., AND KNIGHT, S. C. (1974) Arthr. and Rheum., 17, 513 (Immunologic reactivity in rheumatoid arthritis. Responses to mitogens)

Lockshin, M. D., Eisenhauer, A. C., Kohn, R., Weckser, M., Block, S., AND Mushlin, S. B. (1975) Ibid., 18, 245 (Mitogen responses in RA, SLE and other illnesses: correlation with $T$ and $B$ lymphocyte populations)

Platts-Mills, T. A. E., AND IshizaKa, K. (1975) J. Immunol., 114, 1058 (IgG and IgA diptheria antitoxin responses from human tonsil lymphocytes)

RAfTery, E. B., AND DenMAN, A. M. (1973) Brit. med. J., 2, 452 (An SLE syndrome induced by practolol)

Sherman, N. A., Smith, R. S., AND Middleton, E. (1973) J. Allergy, 52, 13 (Effect of adrenergic compounds, aminophyline and hydrocortisone on in vitro immunoglobulin synthesis by normal human peripheral lymphocytes)

Swanson, M. A., AND Schwarz, R. S. (1967) New Engl. J. Med., 277, 163 (Immuno-suppressive therapy. The relation between clinical response and immunologic competence)

WrIGHT, P. (1975) Brit. med. J., 1, 595 (Untoward effects associated with practolol administration: oculomucocutaneous syndrome)

Wybran, J., CARR, M. C., AND Fudenberg, H. H. (1972) J. clin. Invest., 51, 2537 (The human rosette-forming cell as a marker of a population of thymus-derived cells) 